\title{
Slow Recovery of Blood Glucose in the Insulin Tolerance Test during the Prepartum Transition Period Negatively Impacts the Nutritional Status and Reproductive Performance Postpartum of Dairy Cows
}

\author{
Hsu-Hsun LEE ${ }^{1,2)}$, Katsuya KIDA ${ }^{3)}$, Ryotaro MIURA ${ }^{1,2)}$, Hisashi INOKUMA ${ }^{2)}$, Akio MIYAMOTO ${ }^{4)}$, \\ Chiho KAWASHIMA ${ }^{3)}$, Shingo HANEDA ${ }^{2)}$, Yoh-Ichi MIYAKE ${ }^{2)}$ and Motozumi MATSUI ${ }^{2) *}$ \\ 1) The United Graduate School of Veterinary Sciences, Gifu University, 1-1 Yanagido, Gifu 501-1193, Japan \\ ${ }^{2}$ Department of Clinically Veterinary Sciences, Obihiro University of Agriculture and Veterinary Medicine, Inada-cho, Obihiro, \\ Hokkaido 080-8555, Japan \\ ${ }^{3)}$ Field Center of Animal Science, Obihiro University of Agriculture and Veterinary Medicine, Inada-cho, Obihiro, Hokkaido \\ 080-8555, Japan \\ 4) Graduate School of Animal and Food Hygiene, Obihiro University of Agriculture and Veterinary Medicine, Inada-cho, Obihiro, \\ Hokkaido 080-8555, Japan
}

(Received 23 June 2011/Accepted 19 November 2011/Published online in J-STAGE 2 December 2011)

ABSTRACT. In peripartum dairy cows, insulin resistance (IR) increases to adjust the direction of energy to lactation after calving. To investigate the effect of prepartum IR on postpartum reproductive performance, the insulin tolerance test (ITT) was applied to 15 cows at 3 weeks (Pre21) and 10 days (Pre10) before the predicted calving date. Blood glucose area under the curve $\left(\mathrm{AUC}_{\mathrm{glu}}\right) \mathrm{within}^{120}$ min after administration of $0.05 \mathrm{IU} / \mathrm{kg}$-BW insulin was calculated. The occurrence of first ovulation, days to first artificial insemination (AI) and first AI conception rate were recorded. Nutritional status postpartum was evaluated by blood chemical analysis. Based on $\mathrm{AUC}_{\mathrm{glu}}$ changes from Pre21 to Pre10, cows were classified into either the $\mathrm{AUC}$-up group $\left(\mathrm{AUC}_{\mathrm{glu}}\right.$ increase, $\left.\mathrm{n}=5\right)$ or the $\mathrm{AUC}$-down group $\left(\mathrm{AUC}_{\mathrm{glu}}\right.$ decrease, $\left.\mathrm{n}=10\right)$. There was no difference in the decrease in blood glucose at $30 \mathrm{~min}$ after insulin injection between groups, although glucose recovery from 30 to 60 min during the ITT was slow at Pre10 in the AUC-up group. The AUC-up group had a higher number of days to first AI and high glucose, total protein, globulin, $\gamma$-glutamyltransferase, triacylglycerol levels and a low albumin-globulin ratio at the 14th day postpartum. The present study infers that prepartum slow glucose recovery rather than insulin sensitivity might increase the potential for subclinical health problems postpartum and thus suppress reproductive performance. During the prepartum transition period, glucose dynamics in the ITT can be considered as a new indicator for the postpartum metabolic status and reproductive performance of dairy cows.

KEY WORDS: dairy cows, glucose metabolism, insulin tolerance test, reproductive performance, transition period.

doi: 10.1292/jvms.11-0302; J. Vet. Med. Sci. 74(4): 457-464, 2012

Insulin resistance (IR) is a physiological condition in which body tissues have a lower response to insulin [13]. It includes several physiological changes and mechanisms. Decreased insulin sensitivity is a well-known phenomenon when animals show IR. IR also correlates with some metabolic disorders such as glucose intolerance, ketonemia and ketonuria in humans and other animals [12]. Female mammals usually have IR because of the increase in peripartum energy requirements for fetal growth and lactation [8]. Especially in dairy cows, the abundance of lactation may aggravate the degree of IR and prolong the negative energy balance (NEB) period post partum $[1,22]$. Such metabolic disorders may induce fatty liver and ketosis that sharpen the state of IR and become a vicious circle, particularly in high producing dairy cows [21, 23]. Kawashima et al. [15]

\footnotetext{
*Correspondence to: Matsui, M., Department of Clinically Veterinary Sciences, Obihiro University of Agriculture and Veterinary Medicine, Inada-cho, Obihiro, Hokkaido 080-8555, Japan.

e-mail:mmatsui@obihiro.ac.jp

(C)2012 The Japanese Society of Veterinary Science
}

reported that NEB delays the time of first ovulation by inhibiting estrogen production by dominant follicles. Thus, IR might also be related to reproductive performance.

From the dry period to early lactation, there are major metabolic changes in high-yielding dairy cows. The failure of a cow to adapt to this change may induce health problems in the early postpartum period and worse reproductive performance [3]. In particular, the period of 3 weeks before parturition to early lactation is termed the transition period, which is when dairy cows undergo the greatest metabolic changes [11]. The regulation of IR is an important process for adjusting the direction of energy during the periparturient period. Typically, decreased insulin sensitivity when near to calving has been described [3]. However, there are few studies that indicate the relationship between changes in insulin sensitivity and reproductive performance during the transition period. Thus, clarification of this relationship may help to supply a new strategy for the improvement of farm management.

The insulin tolerance test (ITT) is a tool for evaluating insulin sensitivity by peripheral tissues in animals and used to be applied in human medicine to estimate the state 
of IR. This method calculates insulin sensitivity by injecting a quantitative concentration of insulin into the examinee and measuring the blood glucose level at several time points before and after injection of the insulin [6]. However, the ITT is difficult to use in cows, especially in dairy cows and pregnant cows, because of the difficulty in holding cows and the stress from restraint for a long time during the ITT. Therefore, the details of the changes in blood glucose in dairy cows during the ITT have not yet been clarified.

The objective of this study was to investigate the blood glucose dynamics during the ITT in pregnant dairy cows in the dry period and to confirm the relationship between prepartum insulin sensitivity and postpartum metabolic status or reproductive performance in dairy cows.

\section{MATERIALS AND METHODS}

All experiments were conducted at the Field Center of Animal Science and Agriculture, Obihiro University, and all experimental procedures complied with the Guidelines for the Care and Use of Agricultural Animals of Obihiro University.

Animals: Fifteen pregnant multiparous Holstein dairy cows were assigned to the ITT and the metabolic profile test. All cows had no apparent clinical signs of disease during the experiment period. The mean parity was $2.9 \pm 0.7$ (mean $\pm \mathrm{SD}$ ). Cows were fed a total mixed ration (TMR) consisting of grass, corn silage and concentrate $(1.58 \mathrm{Mcal} /$ $\mathrm{kg}$.DM for NEL, $12.7 \%$ DM for crude protein) from 4 weeks before the predicted calving date until calving. TMR was supplied at 10 a.m.

The ITT was performed at two time points, 3 weeks (Pre21) and 10 days (Pre10) before the predicted calving date. The cows were weighed the day before initiation of the ITT, and body condition scores (BCS) [9] were recorded. Body weight (BW) was used to determine the doses of insulin for the ITT. Average BW was 734.0 \pm 91.0 (mean \pm SD) $\mathrm{kg}$ at Pre21 and $743.9 \pm 76.2 \mathrm{~kg}$ at Pre10. Average BCS was $3.23 \pm 0.38$ at Pre21 and $3.32 \pm 0.36$ at Pre10.

Insulin tolerance test (ITT): The ITT was performed at 9 p.m. (11 hr after feeding). Two days prior to the initiation of the ITT, sterile and nonpyrogenic catheters were inserted into the right or left jugular veins and were maintained by flushing with $5 \mathrm{~m} l$ of heparinized saline $(2,000 \mathrm{IU} / \mathrm{m} l)$ every $12 \mathrm{hr}$ or with diluted heparinized saline $(100 \mathrm{IU} / \mathrm{m} l)$ during frequent sampling. Collection of blood samples and injection of insulin were executed though the inserted catheters; thus, intensive holding and stress could be prevented. The ITT was performed by administering $0.05 \mathrm{IU} / \mathrm{kg}$ of BW of insulin i.v. followed by $5 \mathrm{~m} l$ of heparinized saline $(100 \mathrm{IU} / \mathrm{m} l)$. Blood samples were collected at $-5,5,15,30$, $45,60,90$ and $120 \mathrm{~min}$ relative to the administration of insulin to measure glucose. The blood glucose area under the curve $\left(\mathrm{AUC}_{\mathrm{glu}}\right)$ was calculated by the trapezoid model using the decrease in plasma glucose level (GD) at the time points during the ITT as shown in the following formula. The glucose level 5 min before insulin injection was used as the basic level of glucose. In this study, $\mathrm{AUC}_{\mathrm{glu}}$ was counted as an absolute value for analysis.

$$
\begin{aligned}
\mathrm{AUC}_{\mathrm{glu}}= & (5 \times 5 \mathrm{~min} \mathrm{GD} \div 2)+[10 \times(5 \mathrm{~min} \mathrm{GD}+15 \mathrm{~min} \mathrm{GD}) \div 2] \\
& +[15 \times(15 \mathrm{~min} \mathrm{GD}+30 \mathrm{~min} \mathrm{GD}) \div 2] \\
& +[15 \times(30 \mathrm{~min} \mathrm{GD}+45 \mathrm{~min} \mathrm{GD}) \div 2] \\
& +[15 \times(45 \mathrm{~min} \mathrm{GD}+60 \mathrm{~min} \mathrm{GD}) \div 2] \\
& +[30 \times(60 \mathrm{~min} \mathrm{GD}+90 \mathrm{~min} \mathrm{GD}) \div 2] \\
& +\{[30 \times(90 \mathrm{~min} \mathrm{GD}+120 \mathrm{~min} \mathrm{GD}) \div 2] \text { or }[(\text { time }
\end{aligned}
$$

to glucose base line -90$) \times 90 \min$ GD $\div 2)]\} \mid$

Blood chemical analysis: To measure insulin and glucose levels, blood samples were collected on the day in which catheters were inserted. To evaluate postpartum metabolic status, blood samples were collected on the 14th day (Post14), 21st day (Post21) and 28th day (Post28) post partum. The parameters in the blood chemical analysis were albumin, aspartate transaminase (AST), $\beta$-hydroxybutyric acid (BHBA), glucose, insulin, nonesterified fatty acids (NEFA), total cholesterol (T-cho), triacylglycerol (TG), $\gamma$-glutamyltransferase (GGT), lactate dehydrogenase $(\mathrm{LDH})$, total protein (TP) and globulin.

In each sample, except for globulin and insulin, all parameters were measured using a clinical chemistry automated analyzer (TBA-120FR, Toshiba Medical Systems, Tochigi, Japan). Globulin was calculated as the difference between total protein and albumin. Blood insulin was measured using an enzyme immunoassay kit (Mercodia Bovine Insulin ELISA, Uppsala, Sweden).

Reproductive record: The voluntary waiting period was 55 days, and only one cow was treated with hormones at 161 days after calving. The occurrence of early first ovulation (cows ovulated within 3 weeks postpartum), cows showing clear signs of estrus from 55 to 76 days after calving, days to first artificial insemination (AI), first AI conception rate and days open were recorded to evaluate reproductive performance. To confirm early first ovulation, plasma progesterone was measured at Post14 and Post21, at which point the cows with a plasma progesterone level of $>1 \mathrm{ng} / \mathrm{m} l$ were considered to be cows with early first ovulation [16]. Plasma progesterone was measured by enzyme immunoassays [20]. Signs of estrus were detected 3 times a day, and cows were considered to have clear signs of estrus if they showed standing heat. Only eleven cows had records for days open because four of the cows were culled before they became pregnant.

Statistical analysis: Since insulin sensitivity decreases near calving [3], the relationships between $\mathrm{AUC}_{\mathrm{glu}}$ and postpartum conditions, such as metabolic status and reproductive performance, were analyzed. To evaluate the effect of changes from Pre21 to Pre10, values of (Pre10-Pre21)/Pre10 were defined as the rates of change. $\mathrm{AUC}_{\mathrm{glu}}$, insulin and $\mathrm{BCS}$ rates of change were analyzed in the present study. In addition, the cows were classified into two groups according to the rates of change from Pre21 to Pre10: cows with an $\mathrm{AUC}_{\mathrm{glu}}$ that increased from Pre21 to Pre10 were classified into the AUC-up group $(n=5)$, and those that showed a decrease in $\mathrm{AUC}_{\mathrm{glu}}$ were classified into the $\mathrm{AUC}$-down group $(\mathrm{n}=10)$. Metabolic status and reproductive performance between both groups were compared.

The following analysis examined the origin of differenc- 
es between the AUC-up and AUC-down groups by dissecting glucose dynamics during the ITT and other metabolic factors. Changes in blood glucose from 30 to 60 min after insulin injection, which can be considered as glucose recovery during the ITT, were analyzed.

Data describing the relationship between variations were analyzed by linear regression. The differences in numbers of cows having early first ovulation, cows with signs of estrus and cows conceiving at first AI between the two groups were analyzed with the Pearson's chi-square test. Data describing other differences between two groups were analyzed with the Student's $t$-test. Differences were considered to be significant at $P<0.05$ and to have a tendency at $P<0.1$. Data describing differences between two variables, periods and $\mathrm{AUC}_{\mathrm{glu}}$ changes, were examined by two-way ANOVA. If an interaction was observed between groups, the Tukey-Kramer test was used for multiple comparisons between the groups. All data were analyzed using the JMP ${ }^{\circledR}$ software (SAS Institute, Cary, NC, U.S.A.).

\section{RESULTS}

Changes in $A U C_{g l u}$, glucose and insulin in the prepartum period: In the prepartum period, there was no significant difference in $\mathrm{AUC}_{\mathrm{glu}}$ between Pre21 and Pre10 (Table 1). There were also no significant differences in blood glucose and insulin levels in the same period.

Relationship between prepartum $A U C_{g l u}$ and postpartum metabolic status: $\mathrm{AUC}_{\mathrm{glu}}$ at Pre21 was negatively correlated with insulin at Post14 (Table 2). $\mathrm{AUC}_{\text {glu }}$ at Pre10 was positively correlated with the plasma levels of BHBA, globulin, glucose, AST, LDH, NEFA, TP and GGT at Post14. In contrast, it was negatively correlated with the albuminglobulin ratio (A/G ratio) throughout the period of Post14 to Post28 and with the plasma concentrations of T-cho at Post28. The percentage of change in $\mathrm{AUC}_{\mathrm{glu}}$ from Pre21 to Pre10 $\left(\mathrm{AUC}_{\mathrm{glu}}\right.$ rates of change, $1.2 \pm 44.0$ mean $\left.\pm \mathrm{SD}\right)$ was positively correlated with the plasma levels of globulin, glucose, NEFA,TG, TP, GGT and insulin at Post14 and insulin at Post28. In contrast, it was negatively correlated with the A/G ratio throughout the period of Post14 to Post28 and with the plasma concentrations of T-cho at Post 28.

Relationship between prepartum $A U C_{g l u}$ and reproductive performance: Cows that showed early first ovulation had a lower $\mathrm{AUC}_{\mathrm{glu}}$ at Pre10 $(P<0.05)$ and tended to have lower $\mathrm{AUC}_{\mathrm{glu}}$ rates of change $(P=0.07)$ (Table 3$) . \mathrm{AUC}_{\mathrm{glu}}$ at Pre21 was negatively correlated with days to first AI $(\mathrm{R}=-0.6, P<0.05) . \mathrm{AUC}_{\text {glu }}$ rates of change were positively correlated with days to first $\mathrm{AI}(\mathrm{R}=0.6, P<0.05)$.

Relationship between prepartum $A U C_{\text {glu }}$ changes and postpartum metabolic status: There was no difference in $\mathrm{AUC}_{\mathrm{glu}}$ between the AUC-up and AUC-down groups at Pre21. At Pre10, $\mathrm{AUC}_{\mathrm{glu}}$ was higher in the AUC-up group than in the AUC-down group (Table 4). At Post14, the AUC-up group had higher glucose, TG, TP, globulin and GGT levels than the AUC-down group (Table 5). On the other hand, the $\mathrm{A} / \mathrm{G}$ ratio was low in the AUC-up group.

Relationship between prepartum $A U C_{g l u}$ changes and
Table 1. Changes in $\mathrm{AUC}_{\text {glu }}$, glucose and insulin in the prepartum period

\begin{tabular}{lcc}
\hline & Pre21 & Pre10 \\
\hline AUC $_{\text {glu }}(120 \mathrm{~min} \cdot \mathrm{mg} / \mathrm{d} l)$ & $1,604.2 \pm 311.9$ & $1,542.1 \pm 457.7$ \\
Glucose $(\mathrm{mg} / \mathrm{d} l)$ & $64.5 \pm 5.0$ & $61.5 \pm 6.3$ \\
Insulin $(\mu \mathrm{g} / l)$ & $0.82 \pm 0.46$ & $0.84 \pm 0.52$ \\
\hline
\end{tabular}

Values are expressed as means \pm SD.

reproductive performance: A higher number of days to first AI were observed in the AUC-up group (Table 6). The AUC-down group tended to have more cows with early first ovulation $(P=0.10)$ and clear signs of estrus from days 55 to $76(P=0.05)$ than the AUC-up group. The first AI conception rate and days open did not differ between the groups.

Glucose dynamics during the ITT and other information: GD at $30 \mathrm{~min}$ and glucose recovery during the ITT showed no significant differences between the two groups at Pre21. In the AUC-down group, GD at 30 min decreased from Pre21 to Pre10 $(P<0.05$, Fig. 1a). Glucose recovery of the AUC-up group was slower than that of the AUC-down group at Pre10 $(P<0.05$, Fig. 1b). At Pre10, plasma insulin levels were higher in the AUC-up group (Fig. 2a). From Pre21 to Pre10, the AUC-up group showed higher insulin rates of change than the AUC-down group (Fig. 2b). From Pre21 to Pre10, the BCS rates of change were negatively correlated with the insulin rates of change (Fig. 3).

\section{DISCUSSION}

In general, increased $\mathrm{AUC}_{\text {glu }}$ implies higher insulin sensitivity and good glucose utilization. Interestingly, in the present study, increased $\mathrm{AUC}_{\mathrm{glu}}$ from Pre21 to Pre10 had a negative impact on the nutritional status and reproductive performance postpartum in dairy cattle. The reason for increased $\mathrm{AUC}_{\mathrm{glu}}$ in the $\mathrm{AUC}$-up group was slower glucose recovery during the ITT rather than higher insulin sensitivity. This finding indicates that glucose metabolism rather than insulin sensitivity during the prepartum transition period had a greater impact on postpartum metabolic status and reproductive performance.

Results clearly indicate that Pre10 $\mathrm{AUC}_{\mathrm{glu}}$ and $\mathrm{AUC}_{\mathrm{glu}}$ rates of change were significantly related to the metabolic profiles at Post14. Even when values of all parameters were within the normal range, significant relationships between parameters of postpartum metabolic profiles and Pre10 $\mathrm{AUC}_{\mathrm{glu}}$ were observed. Thus, although cows were not seen showing clinical symptoms, prepartum $\mathrm{AUC}_{\text {glu }}$ might affect postpartum metabolic status. In addition, reproductive performance, as indicated by early first ovulation and days to first $\mathrm{AI}$, were related to the prepartum $\mathrm{AUC}_{\mathrm{glu}}$ profile. These findings suggest that the state of IR near parturition has a strong influence on early postpartum metabolic status and subsequent ovarian function.

In the days close to calving, insulin sensitivity is considered to decrease in cows [3]. The present study shows that ten cows (AUC-down group) had a decreased $\mathrm{AUC}_{\mathrm{glu}}$ from Pre21 to Pre10. However, five cows (AUC-up group) 
Table 2. Relationship between prepartum $\mathrm{AUC}_{\text {glu }}$ and postpartum metabolic status $(\mathrm{n}=15)$

\begin{tabular}{|c|c|c|c|c|c|c|c|c|}
\hline & & \multirow[t]{2}{*}{ Values } & \multicolumn{2}{|c|}{ Relative to Pre $21 \mathrm{AUC}_{\text {glu }}$} & \multicolumn{2}{|c|}{ Relative to Pre10 $\mathrm{AUC}_{\mathrm{glu}}$} & \multicolumn{2}{|c|}{$\begin{array}{c}\text { Relative to } \\
\text { AUC }_{\text {glu }} \text { rates of change }\end{array}$} \\
\hline & & & $\mathrm{R}$ & $P$ value & $\mathrm{R}$ & $P$ value & $\mathrm{R}$ & $P$ value \\
\hline \multirow[t]{13}{*}{ Post14 } & $\mathrm{BHBA}(\mathrm{mmol} / \mathrm{l})$ & $802.9 \pm 237.3$ & 0.43 & NS & 0.57 & $*$ & 0.16 & NS \\
\hline & Albumin $(\mathrm{g} / \mathrm{d} l)$ & $3.0 \pm 0.5$ & -0.04 & NS & 0.49 & 0.06 & 0.44 & NS \\
\hline & Globulin $(\mathrm{g} / \mathrm{d} l)$ & $3.0 \pm 0.8$ & -0.24 & NS & 0.67 & $* *$ & 0.69 & $* *$ \\
\hline & $\mathrm{A} / \mathrm{G}$ ratio & $1.02 \pm 0.13$ & 0.29 & NS & -0.68 & $* *$ & -0.71 & $* *$ \\
\hline & Glucose $(\mathrm{mg} / \mathrm{d} l)$ & $41.3 \pm 11.9$ & -0.37 & NS & 0.53 & $*$ & 0.66 & $* *$ \\
\hline & AST (IU/l) & $73.0 \pm 17.4$ & -0.01 & NS & 0.69 & $* *$ & 0.48 & 0.07 \\
\hline & LDH (IU/l) & $657.4 \pm 178.2$ & -0.02 & NS & 0.52 & $*$ & 0.45 & 0.09 \\
\hline & NEFA $(\mu \mathrm{Eq} / l)$ & $315.9 \pm 154.9$ & -0.24 & NS & 0.57 & $*$ & 0.59 & $*$ \\
\hline & T-cho $(\mathrm{mg} / \mathrm{d} l)$ & $83.7 \pm 29.3$ & -0.25 & NS & 0.25 & NS & 0.38 & NS \\
\hline & $\mathrm{TG}(\mathrm{mg} / \mathrm{d} l)$ & $2.6 \pm 0.9$ & -0.24 & NS & 0.5 & 0.06 & 0.58 & * \\
\hline & $\mathrm{TP}(\mathrm{g} / \mathrm{d} l)$ & $6.0 \pm 1.3$ & -0.16 & NS & 0.61 & $*$ & 0.6 & $*$ \\
\hline & GGT (IU/l) & $18.2 \pm 6.3$ & -0.22 & NS & 0.77 & $* * *$ & 0.73 & $* *$ \\
\hline & Insulin $(\mu \mathrm{g} / l)$ & $0.2 \pm 0.19$ & -0.57 & $*$ & 0.16 & NS & 0.59 & $*$ \\
\hline \multirow[t]{13}{*}{ Post21 } & BHBA & $936.5 \pm 490.7$ & 0.29 & NS & -0.14 & NS & -0.28 & NS \\
\hline & Albumin & $3.3 \pm 0.4$ & 0.38 & NS & -0.26 & NS & -0.47 & 0.08 \\
\hline & Globulin & $3.4 \pm 0.6$ & -0.08 & NS & 0.49 & 0.06 & 0.36 & NS \\
\hline & $\mathrm{A} / \mathrm{G}$ ratio & $0.96 \pm 0.14$ & 0.3 & NS & -0.67 & $* *$ & -0.66 & $* *$ \\
\hline & Glucose & $42.4 \pm 7.2$ & 0.24 & NS & 0.27 & NS & 0.03 & NS \\
\hline & AST & $88.3 \pm 33.6$ & -0.01 & NS & 0.26 & NS & 0.14 & NS \\
\hline & $\mathrm{LDH}$ & $772.5 \pm 213.3$ & 0.14 & NS & 0.18 & NS & 0.03 & NS \\
\hline & NEFA & $305.8 \pm 150.2$ & 0.26 & NS & -0.11 & NS & -0.26 & NS \\
\hline & T-cho & $103.9 \pm 25$ & 0.1 & NS & -0.39 & NS & -0.37 & NS \\
\hline & $\mathrm{TG}$ & $2.6 \pm 0.6$ & -0.09 & NS & 0.3 & NS & 0.26 & NS \\
\hline & $\mathrm{TP}$ & $6.7 \pm 0.8$ & 0.11 & NS & 0.25 & NS & 0.07 & NS \\
\hline & GGT & $19.5 \pm 3.9$ & 0.32 & NS & 0.22 & NS & -0.06 & NS \\
\hline & Insulin & $0.16 \pm 0.09$ & -0.14 & NS & 0.16 & NS & 0.26 & NS \\
\hline \multirow[t]{13}{*}{ Post28 } & BHBA & $786.1 \pm 256.7$ & 0.35 & NS & -0.14 & NS & -0.37 & NS \\
\hline & Albumin & $3.2 \pm 0.4$ & 0.15 & NS & -0.35 & NS & -0.37 & NS \\
\hline & Globulin & $3.4 \pm 0.5$ & -0.2 & NS & 0.3 & NS & 0.3 & NS \\
\hline & $\mathrm{A} / \mathrm{G}$ ratio & $0.95 \pm 0.13$ & 0.32 & NS & -0.56 & $*$ & -0.58 & $*$ \\
\hline & Glucose & $45.3 \pm 10.6$ & -0.21 & NS & 0.12 & NS & 0.2 & NS \\
\hline & AST & $71.6 \pm 21.7$ & 0.09 & NS & -0.03 & NS & -0.12 & NS \\
\hline & $\mathrm{LDH}$ & $737.7 \pm 207.5$ & 0.14 & NS & 0.23 & NS & 0.04 & NS \\
\hline & NEFA & $197.9 \pm 64.2$ & 0.3 & NS & 0.05 & NS & -0.09 & NS \\
\hline & T-cho & $114.4 \pm 25.3$ & 0.02 & NS & -0.54 & $*$ & -0.44 & $* *$ \\
\hline & TG & $2.8 \pm 0.6$ & 0.04 & NS & 0.31 & NS & 0.2 & NS \\
\hline & TP & $6.5 \pm 0.8$ & -0.06 & NS & 0.02 & NS & 0.01 & NS \\
\hline & GGT & $20.3 \pm 5.2$ & 0.01 & NS & 0.22 & NS & 0.13 & NS \\
\hline & Insulin & $0.25 \pm 0.25$ & -0.28 & NS & 0.52 & * & 0.56 & * \\
\hline
\end{tabular}

*, ** and ***: $P<0.05, P<0.01$ and $P<0.001$, respectively. NS: $P>0.1$. Values are expressed as means $\pm \mathrm{SD}$.

Table 3. Prepartum $\mathrm{AUC}_{\mathrm{glu}}$ in cows with or without early first ovulation post partum

\begin{tabular}{lcccc}
\hline & $\mathrm{n}$ & $\begin{array}{c}\text { Pre21 } \mathrm{AUC}_{\mathrm{glu}} \\
(120 \mathrm{~min} \cdot \mathrm{mg} / \mathrm{d} l)\end{array}$ & $\begin{array}{c}\text { Pre10 } \mathrm{AUC}_{\mathrm{glu}} \\
(120 \mathrm{~min} \cdot \mathrm{mg} / \mathrm{d} l)\end{array}$ & $\begin{array}{c}\mathrm{AUC}_{\mathrm{glu}} \text { rates of change } \\
(\%)\end{array}$ \\
\hline Cows having early ovulation & 4 & $1,607.8 \pm 86.0$ & $1,075.2 \pm 177.6^{\mathrm{a})}$ & $-33.1 \pm 10.1$ \\
Cows not having early ovulation & 11 & $1,602.9 \pm 107.6$ & $1,711.9 \pm 111.4^{\mathrm{b})}$ & $13.7 \pm 13.3$ \\
\hline
\end{tabular}

a, b) Different superscripts indicate significant differences between groups $(P<0.05)$. Values are expressed as means \pm SEM.

had an increased $\mathrm{AUC}_{\mathrm{glu}}$ at Pre10. Interestingly, delayed resumption of ovarian function was observed in the AUC-up group. There are few studies that have examined the effect of prepartum IR on postpartum ovarian function.
To clarify the difference between the AUC-up and AUCdown groups, the glucose dynamics during the ITT were analyzed. Since there were no differences in GD at $30 \mathrm{~min}$ after insulin injection between the AUC-up and AUC-down 
Table 4. The differences in $\mathrm{AUC}_{\text {glu }}$ between the AUC-up and AUC-down groups

\begin{tabular}{lclc}
\hline & $\mathrm{n}$ & \multicolumn{2}{c}{$\mathrm{AUC}_{\mathrm{glu}}(120 \mathrm{~min} \cdot \mathrm{mg} / \mathrm{d} l)$} \\
\cline { 3 - 4 } & & \multicolumn{1}{c}{$\operatorname{Pre} 21$} & $\operatorname{Pre} 10$ \\
\hline AUC-up group & 5 & $1,468.4 \pm 207.4$ & $2,004.7 \pm 159.8^{\mathrm{a})}$ \\
AUC-down group & 10 & $1,672.1 \pm 63.6$ & $1,310.8 \pm 95.2^{\mathrm{b})}$ \\
\hline
\end{tabular}

a, b) Different superscripts indicate significant differences between groups $(P<0.05)$. Values are expressed as means \pm SEM.

groups, insulin sensitivity was considered to be similar between the two groups. On the other hand, glucose recovery was slow at Pre10 in the AUC-up group. Thus, the increases in $\mathrm{AUC}_{\mathrm{glu}}$ from Pre21 to Pre10 were more likely due to slower glucose recovery, which might have been caused by less gluconeogenesis or slow insulin clearance. Furthermore, high levels of insulin in the AUC-up group might be another reason for slower glucose recovery [10].

Some studies have indicated that insulin may affect
Table 5. The differences in metabolic status at Post14 between the AUC-up group and AUC-down group

\begin{tabular}{lccc}
\hline & $\begin{array}{c}\text { AUC-up group } \\
(\mathrm{n}=5)\end{array}$ & $\begin{array}{c}\text { AUC-down group } \\
(\mathrm{n}=10)\end{array}$ & $P$ value \\
\hline BHBA $(\mathrm{mmol} / l)$ & $840.8 \pm 109.4$ & $783.9 \pm 77.3$ & $\mathrm{NS}$ \\
Albumin $(\mathrm{g} / \mathrm{d} l)$ & $3.3 \pm 0.2$ & $2.8 \pm 0.2$ & $\mathrm{NS}$ \\
Globulin $(\mathrm{g} / \mathrm{d} l)$ & $3.7 \pm 0.3$ & $2.7 \pm 0.2$ & $* *$ \\
A/G ratio & $0.88 \pm 0.02$ & $1.08 \pm 0.03$ & $*$ \\
Glucose $(\mathrm{mg} / \mathrm{d} l)$ & $51.2 \pm 4.5$ & $36.4 \pm 3.1$ & $*$ \\
AST $(\mathrm{IU} / l)$ & $81.0 \pm 7.6$ & $69.0 \pm 5.4$ & $\mathrm{NS}$ \\
NEFA $(\mu \mathrm{Eq} / l)$ & $381.4 \pm 68.3$ & $283.1 \pm 48.3$ & $\mathrm{NS}$ \\
T-cho $(\mathrm{mg} / \mathrm{d} l)$ & $95.7 \pm 12.9$ & $77.6 \pm 9.1$ & $\mathrm{NS}$ \\
TG $(\mathrm{mg} / \mathrm{d} l)$ & $3.3 \pm 0.4$ & $2.2 \pm 0.2$ & $*$ \\
TP $(\mathrm{g} / \mathrm{d} l)$ & $7.0 \pm 0.4$ & $5.5 \pm 0.3$ & $*$ \\
GGT $(\mathrm{IU} / l)$ & $22.8 \pm 3.4$ & $15.9 \pm 1.4$ & $* * *$ \\
\hline
\end{tabular}

$*, * *$ and $* * *: P<0.05, P<0.01$ and $P<0.001$, respectively. NS: $P>0.1$. Values are expressed as means \pm SEM.

Table 6. The differences in reproductive performance between the AUC-up and AUC-down groups

\begin{tabular}{|c|c|c|c|}
\hline & $\begin{array}{c}\text { AUC-up group } \\
(\mathrm{n}=5)\end{array}$ & $\begin{array}{l}\text { AUC-down group } \\
(\mathrm{n}=10)\end{array}$ & $P$ value \\
\hline Number of cows having early ovulation (\%) & $0(0 \%)$ & $4(40 \%)$ & 0.10 \\
\hline Number of cows with signs of estrus $\left.{ }^{a}\right)(\%)$ & $0(0 \%)$ & $5(50 \%)$ & 0.05 \\
\hline Number of cows conceiving at first AI (\%) & $1(20 \%)$ & $5(50 \%)$ & NS \\
\hline $\begin{array}{l}\text { Days to } 1 \text { st AI } \\
\text { (Range) }\end{array}$ & $\begin{array}{l}120.6 \pm 15.6 \\
(89-163)\end{array}$ & $\begin{array}{c}80.9 \pm 5.4 \\
(56-109)\end{array}$ & ** \\
\hline $\begin{array}{l}\text { Days open }{ }^{\text {b) }} \\
\text { (Range) }^{\text {(Rage }}\end{array}$ & $\begin{array}{l}154.3 \pm 40.0 \\
(89-227)\end{array}$ & $\begin{array}{l}104.6 \pm 14.8 \\
(56-176)\end{array}$ & NS \\
\hline
\end{tabular}

**: $P<0.01$. NS: $P>0.1$. Values are expressed as means \pm SEM. a) Cows showed clear signs of estrus from days 55 to 76 after calving. b) Only 11 cows were recorded because 4 cows were culled before they became pregnant. AUC-up group: $n=3$. AUC-down group: $n=8$.

a

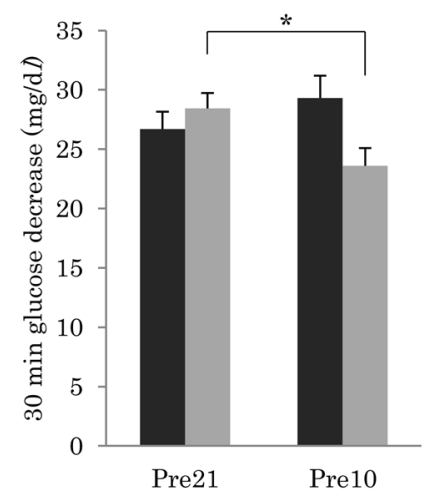

b

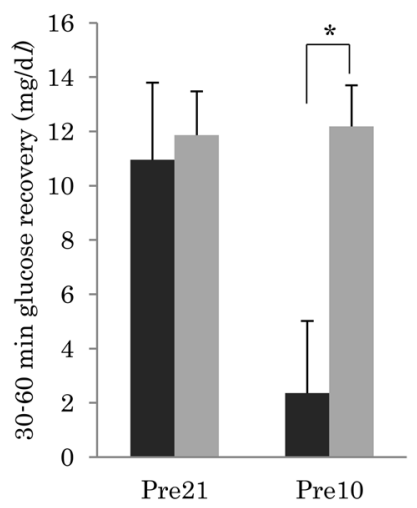

Fig. 1. The differences in glucose dynamics during the ITT at Pre21 and Pre10 between the AUC-up group ( $\mathbf{0}$ ) and AUC-down group ( $\square$ ). As shown in Materials and Methods, cows with increased $\mathrm{AUC}_{\mathrm{glu}}$ from Pre21 to Pre10 were classified into the AUC-up group, and those with decreased $\mathrm{AUC}_{\mathrm{glu}}$ were classified into the AUC-down group. a) GD at $30 \mathrm{~min}$ after insulin injection. b) Glucose recovery from $30 \mathrm{~min}$ to $60 \mathrm{~min}$ during the ITT. Data are presented as means \pm SEM. $*: P<0.05$. 
a

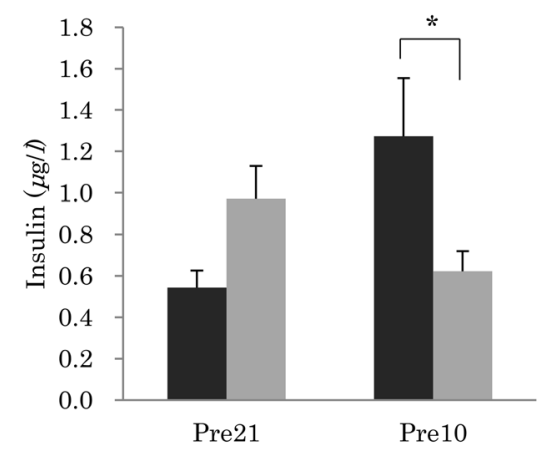

b

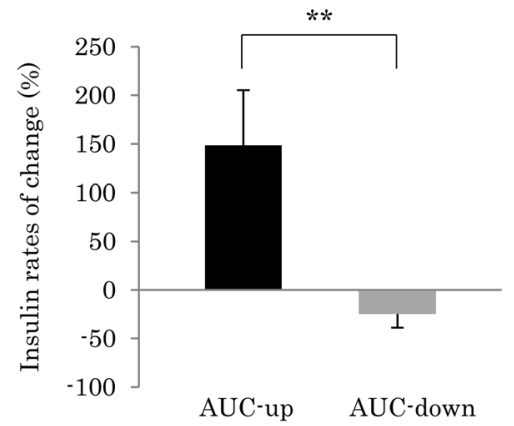

Fig. 2. Comparison of insulin levels at Pre21 and Pre10 between the AUC-up group ( $\square$ ) and AUC-down group (ロ). a) The differences in insulin levels at Pre21 and Pre10. b) The differences in insulin rates of change from Pre21 to Pre10. The insulin level at -5 min during the ITT was analyzed. Data are presented as means \pm SEM. * and $* *: P<0.05$, and $P<0.01$, respectively.

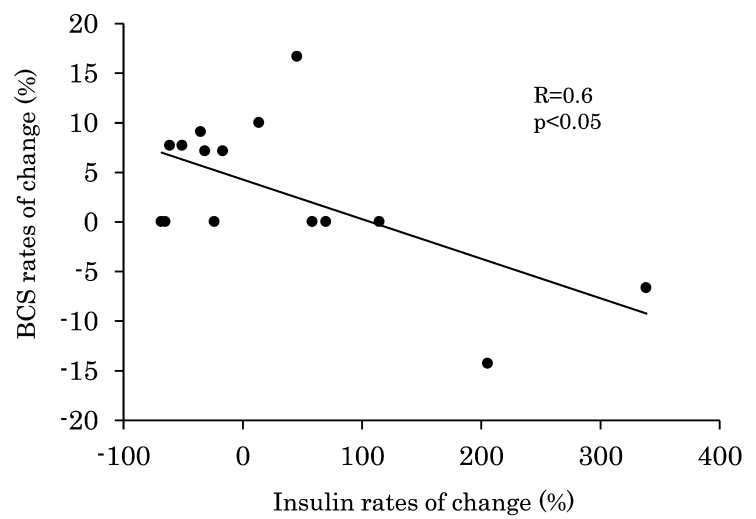

Fig. 3. Relationship between BCS rates of change from Pre21 to Pre10 and insulin rates of change from Pre21 to Pre10.

long-term dietary intake and weight regulation in ruminants $[19,24]$. In dairy cows, long-term infusion of insulin for hyperinsulinemic-euglycemic clamp techniques generally depresses dietary intake [2]. In the present study, the AUC-up group might have had decreased dietary intake before calving because the insulin level increased from Pre21 to Pre10 in the AUC-up group. BCS in the AUC-up group tended to decrease together with increased insulin from Pre21 to Pre10 ( $P=0.06$, data not shown). Therefore, the AUC-up group might have had a negative nutritional balance in the peripartum period.

According to the results of blood chemical analysis in the AUC-up group during the postpartum period, this group of cows had a high incidence of subclinical health problems. It also showed high glucose, TP and globulin levels, and a low $\mathrm{A} / \mathrm{G}$ ratio in the early postpartum period. However, there was no difference in the albumin level compared with the AUC-down group; thus, the high TP level was caused by the high globulin level. Globulin could be considered an indication of inflammation. A sign of high incidence of periparturient diseases is high globulin and glucose levels in early postpartum [17], as well as a lower $\mathrm{A} / \mathrm{G}$ ratio in the AUC-up group compared with the AUC-down group.

The AUC-up group also showed high GGT and TG levels compared with the AUC-down group in the postpartum period. GGT is considered to be an indicator for ketosis, hepatic inflammation and hepatic damage. Steen et al. [23] reported that the GGT level increased significantly in cows with fatty liver compared with normal cows. Some of the animals with ketosis also had elevated GGT levels, as seen in another study [14]. The plasma TG level is also affected by dietary fat. Feeding dietary fat to lactating cows linearly increases the plasma TG level [7].

Taken together, in the AUC-up group, slow glucose recovery might induce postpartum health problems, such as liver dysfunction and/or inflammation.

The reproductive performance observed in the AUC-up group is consistent with a previous study that showed a delay in first ovulation leading to a higher number of days to first AI in dairy cows [16]. Kawashima et al. [15] reported that the first postpartum ovulation is delayed in cows having a lower nutrition status. Zulu et al. [25] also reported that poor liver function affects ovarian function during the early postpartum period in dairy cows. Liver dysfunction impairs release of insulin-like growth factor-1 from the liver and then delays postpartum ovarian resumption [5, 25]. In addition, Law et al. [18] reported that the globulin concentration is negatively associated with peak progesterone during early- and mid-lactation. Bertoni et al. [4] indicated that release of proinflammatory cytokines during the periparturient period impairs milk yield and fertility. Therefore, liver dysfunction and/or inflammation in the AUC-up group may be suppressive factors for reproduction.

Collectively, the AUC-up group tended to exhibit delayed first ovulation after calving, and delayed estrus cycles 
might prolong the days to first AI. Even the conception rate did not differ between the two groups, with the AUC-down group tending to have more cows with clear signs of estrus during the early breeding period. In the AUC-down group, five cows showed clear signs of estrus from days 55 to 76 and $80 \%(4 / 5)$ conceived after the first AI (data not shown). It could be considered that the AUC-down group tended to recover reproductive function earlier than the AUC-up group after calving. Although the effect of prepartum insulin sensitivity on reproductive performance in the postpartum period was not clarified, the present study suggests that slow glucose level recovery during the ITT in the prepartum period negatively affects reproduction in dairy cows after calving.

In conclusion, the present study inferred that changes in $\mathrm{AUC}_{\mathrm{glu}}$ from Pre21 to Pre10 could be used to estimate the metabolic status of a cow. The slower glucose recovery observed in the AUC-up group might increase the potential for subclinical health problems (such as subclinical liver dysfunction and/or inflammation) in the postpartum period and then suppress reproductive performance. During the prepartum transition period, glucose metabolism rather than insulin sensitivity had a greater impact on postpartum metabolic status and reproductive performance. Therefore, changes in glucose dynamics after insulin injection during the prepartum transition period can be considered as new indicators for metabolic status and reproductive performance post partum. Further investigation is required to assess whether these indicators can be applied at different farms and what mechanisms affect glucose dynamics during the prepartum transition period.

ACKNOWLEDGMENTS. The first author gratefully acknowledges scholarships from the Iwatani Naoji Foundation, Japan Student Services Organization (JASSO) and Northern Regions Center (NRC).

\section{REFERENCES}

1. Balogh, O., Szepes, O., Kovacs, K., Kulcsar, M., Reiczigel, J., Alcazar, J. A., Keresztes, M., Febel, H., Bartyik, J., Fekete, S. G., Fesus, L. and Huszenicza, G. 2008. Interrelationships of growth hormone AluI polymorphism, insulin resistance, milk production and reproductive performance in Holstein-Friesian cows. Vet. Med. (Praha) 53: 604-616.

2. Bareille, N. and Faverdin, P. 1996. Modulation of the feeding response of lactating dairy cows to peripheral insulin administration with or without a glucose supply. Reprod. Nutr. Dev. 36: 83-93. [Medline] [CrossRef]

3. Bell, A. W. 1995. Regulation of organic nutrient metabolism during transition from late pregnancy to early lactation. $J$. Anim. Sci. 73: 2804-2819. [Medline]

4. Bertoni, G., Trevisi, E., Han, X. and Bionaz, M. 2008. Effects of inflammatory conditions on liver activity in puerperium period and consequences for performance in dairy cows. $J$. Dairy Sci. 91: 3300-3310. [Medline] [CrossRef]

5. Butler, W. R. 2000. Nutritional interactions with reproductive performance in dairy cattle. Anim. Reprod. Sci. 60-61: 449-457. [Medline] [CrossRef]

6. Castracane, V. D. and Kauffman, R. P. 2003. Controlling
PCOS, part 1: assessing insulin sensitivity. Contemp. Ob. Gyn. 48: $30-48$.

7. Choi, B. R. and Palmquist, D. L. 1996. High fat diets increase plasma cholecystokinin and pancreatic polypeptide, and decrease plasma insulin and feed intake in lactating cows. $J$. Nutr. 126: 2913-2919. [Medline]

8. Debras, E., Grizard, J., Aina, E., Tesseraud, S., Champredon, C. and Arnal, M. 1989. Insulin sensitivity and responsiveness during lactation and dry period in goats. Am. J. Physiol. 256: E295-E302. [Medline]

9. Ferguson, J. D., Galligan, D. T. and Thomsen, N. 1994. Principal descriptors of body condition score in Holstein cows. $J$. Dairy Sci. 77: 2695-2703. [Medline] [CrossRef]

10. Greenfield, R. B., Cecava, M. J. and Donkin, S. S. 2000. Changes in mRNA expression for gluconeogenic enzymes in liver of dairy cattle during the transition to lactation. J. Dairy Sci. 83: 1228-1236. [Medline] [CrossRef]

11. Grummer, R. R. 1995. Impact of changes in organic nutrient metabolism on feeding the transition dairy cow. J. Anim. Sci. 73: 2820-2833. [Medline]

12. Hayirli, A. 2006. The role of exogenous insulin in the complex of hepatic lipidosis and ketosis associated with insulin resistance phenomenon in postpartum dairy cattle. Vet. Res. Commun. 30: 749-774. [Medline] [CrossRef]

13. Kahn, C. R. 1978. Insulin resistance, insulin sensitivity, and insulin unresponsiveness: a necessary distinction. Metabolism 27: 1893-1902. [Medline] [CrossRef]

14. Kauppinen, K. 1984. ALAT, AP, ASAT, GGT, OCT activities and urea and total bilirubin concentrations in plasma of normal and ketotic dairy cows. Zentralbl. Veterinarmed. A 31: 567-576. [Medline] [CrossRef]

15. Kawashima, C., Fukihara, S., Maeda, M., Kaneko, E., Montoya, C. A., Matsui, M., Shimizu, T., Matsunaga, N., Kida, K., Miyake, Y., Schams, D. and Miyamoto, A. 2007. Relationship between metabolic hormones and ovulation of dominant follicle during the first follicular wave post-partum in highproducing dairy cows. Reproduction 133: 155-163. [Medline] [CrossRef]

16. Kawashima, C., Kaneko, E., Amaya Montoya, C., Matsui, M., Yamagishi, N., Matsunaga, N., Ishii, M., Kida, K., Miyake, Y. and Miyamoto, A. 2006. Relationship between the first ovulation within three weeks postpartum and subsequent ovarian cycles and fertility in high producing dairy cows. J. Reprod. Dev. 52: 479-486. [Medline] [CrossRef]

17. Kida, K. 2002. The metabolic profile test: its practicability in assessing feeding management and periparturient diseases in high yielding commercial dairy herds. J. Vet. Med. Sci. 64: 557-563. [Medline] [CrossRef]

18. Law, R. A., Young, F. J., Patterson, D. C., Kilpatrick, D. J., Wylie, A. R. and Mayne, C. S. 2009. Effect of dietary protein content on the fertility of dairy cows during early and mid lactation. J. Dairy Sci. 92: 2737-2746. [Medline] [CrossRef]

19. McCann, J. P., Bergman, E. N. and Beermann, D. H. 1992. Dynamic and static phases of severe dietary obesity in sheep: food intakes, endocrinology and carcass and organ chemical composition. J. Nutr. 122: 496-505. [Medline]

20. Miyamoto, A., Okuda, K., Schweigert, F. J. and Schams, D. 1992. Effect of basic fibroblastic growth factor, transforming growth factor- $\beta$ and nerve growth factor on the secretory function of the bovine corpus luteum in vitro. J. Endocrinol. 135: 103-114. [Medline] [CrossRef]

21. Ohtsuka, H., Koiwa, M., Hatsugaya, A., Kudo, K., Hoshi, F., Itoh, N., Yokota, H., Okada, H. and Kawamura, S. 2001. Relationship between serum TNF activity and insulin resistance in 
dairy cows affected with naturally occurring fatty liver. $J$. Vet. Med. Sci. 63: 1021-1025. [Medline] [CrossRef]

22. Reist, M., Erdin, D. K., von Euw, D., Tschümperlin, K. M., Leuenberger, H., Hammon, H. M., Morel, C., Philipona, C., Zbinden, Y., Künzi, N. and Blum, J. W. 2003. Postpartum reproductive function: association with energy, metabolic and endocrine status in high yielding dairy cows. Theriogenology 59: 1707-1723. [Medline] [CrossRef]

23. Steen, A., Gronstol, H. and Torjesen, P. A. 1997. Glucose and insulin responses to glucagon injection in dairy cows with ketotis and fatty liver. Zentralbl. Veterinarmed. A 44: 521-530.
[Medline]

24. Vandermeerschen-Doizé, F., Bouchat, J. C., Bouckoms-Vandermeir, M. A. and Paquay, R. 1983. Effects of long-term ad libitum feeding on plasma lipid components and blood glucose, $\beta$-hydroxybutyrate and insulin concentrations in lean adult sheep. Reprod. Nutr. Dev. 23: 51-63. [Medline] [CrossRef]

25. Zulu, V. C., Sawamukai, Y., Nakada, K., Kida, K. and Moriyoshi, M. 2002. Relationship among insulin-like growth factor-I, blood metabolites and postpartum ovarian function in dairy cows. J. Vet. Med. Sci. 64: 879-885. [Medline] [CrossRef] 